\title{
ANALISIS KESESUAIAN DAN KETERSEDIAAN LAHAN SERTA ARAHAN PENGEMBANGAN KOMODITAS PERTANIAN DI KABUPATEN KEPULAUAN MERANTI PROVINSI RIAU
}

\section{An Analysis of Land Suitability and Availability and Referral Development Agricultural Commodities in Kepulauan Meranti Regency, Riau Province}

\section{Santun Risma Pandapotan Sitorus ${ }^{1)^{*}}$, Muhammad Jalaluddin ${ }^{2)}$, dan Dyah Retno Panuju1)}

1) Departemen Ilmu Tanah dan Sumberdaya Lahan, Fakultas Pertanian IPB, J1. Meranti Kampus IPB Darmaga Bogor 16680

2) Alumni Program Studi Perencanaan dan Pengembangan Wilayah, Departemen Ilmu Tanah dan Sumberdaya Lahan, Fakultas Pertanian IPB, Bogor 16680

\begin{abstract}
Kepulauan Meranti Regency is a district which (formerly part of) Bengkalis. It was established after Law No. 12, dated January 16, 2009. Since the district is newly developed agricultural development policy is still unavailable. Many land related aspects should be considered in order to have more effective and efficient land utilization. This research aims: (1) to know potential commodity of Kepulauan Meranti Regency, (2) to analyze land suitability for various agricultural commodities, (3) to review and analyze the availability of potential land to develop various agricultural commodities, and (4) to recommend the direction of agricultural commodities development. Results showed that suitable and available land for development of agricultural commodities is about 108,277 ha. The District Merbau is suitable and available for sago (plantation), cassava (food crops), guava (fruits) and great chili, cayenne pepper and cucumber (vegetables). Pulau Merbau is suitable and available for rubber and nut (plantation). Rangsang is suitable and available for sapodilla and pineapple (fruits). Rangsang Barat is suitable and available for coffee and nut (plantation), banana, papaya and mangosteen (fruits). Tebing Tinggi is suitable and available for sweet potatoes and corn (food crops) and great chili, cayenne pepper, chickpea and cucumber (vegetables). Tebing Tinggi Barat is suitable and available for sago (plantation), sweet potatoes (food crops) and papaya, breadfruit and pineapple, while District Tebing Tinggi Timur is mostly suitable for sago plantation.
\end{abstract}

Keywords: Availability, comparative and competitive advantages, suitability

\section{ABSTRAK}

Kabupaten Kepulauan Meranti merupakan kabupaten hasil pemekaran dari Kabupaten Bengkalis. Dasar hukum berdirinya Kabupaten Kepulauan Meranti adalah Undang-undang Nomor 12 Tahun 2009, tanggal 16 Januari 2009. Mengingat usia kabupaten ini yang relatif muda, arahan pengembangan komoditas pertanian belum tersedia secara lengkap. Banyak aspek lahan yang harus diperhatikan agar pemanfaatan atau penggunaan lahan untuk pengembangan komoditas wilayah lebih efektif dan berdaya guna. Tujuan penelitian ini adalah: (1) Mengetahui komoditas unggulan di Kabupaten Kepulauan Meranti, (2) Menganalisis kesesuaian lahan untuk pengembangan berbagai komoditas pertanian, (3) Mengkaji dan menganalisis ketersediaan lahan yang berpotensi pengembangan untuk berbagai komoditas pertanian, dan (4) Menyusun arahan pengembangan komoditas pertanian. Hasil penelitian menunjukkan luas lahan sesuai dan tersedia di Kabupaten Kepulauan Meranti untuk pengembangan komoditas unggulan sebesar 108,277 ha. Komoditas yang dapat dikembangkan tiap kecamatan adalah sebagai berikut: Kecamatan Merbau adalah sagu (tanaman perkebunan), ketela pohon (tanaman pangan), jambu biji (buah-buahan) dan cabe besar, cabe rawit dan ketimun (sayur-sayuran); Pulau Merbau adalah karet dan pinang (tanaman perkebunan); Rangsang adalah sawo dan nenas (buah-buahan). Rangsang Barat adalah kopi dan pinang (tanaman perkebunan), pisang, pepaya dan manggis (buah-buahan); Tebing Tinggi adalah ketela rambat dan jagung (tanaman pangan) dan cabe besar, cabe rawit, kacang panjang dan ketimum (sayur-sayuran); Tebing Tinggi Barat adalah sagu (tanaman perkebunan), ketela rambat (tanaman pangan), pepaya, sukun dan nenas (buah-buahan); dan Kecamatan Tebing Tinggi Timur komoditas yang dapat dikembangkan adalah sagu untuk tanaman perkebunan.

Kata kunci: Ketersediaan, keunggulan komparatif dan kompetitif, kesesuaian 


\section{PENDAHULUAN}

Kabupaten Kepulauan Meranti terbentuk dari hasil pemekaran Kabupaten Bengkalis. Dasar hukum berdirinya Kabupaten Kepulauan Meranti adalah Undangundang nomor 12 tahun 2009, tanggal 16 Januari 2009. Secara geografis Kabupaten Kepulauan Meranti berada pada koordinat antara $0^{\circ} 42^{\prime} 30^{\prime \prime}-1^{\circ} 28^{\prime} 0^{\prime \prime} L U$, dan $102^{\circ}$ $12^{\prime} 0^{\prime \prime}-103^{\circ} 10^{\prime} 0^{\prime \prime} B T$ dan terletak pada bagian pesisir timur Pulau Sumatera. Luas wilayah Kabupaten Kepulauan Meranti 3,707.84 $\mathrm{Km}^{2}$, terdiri dari pulau-pulau dan lautan. Kabupaten Kepulauan Meranti terdiri atas 4 pulau utama yaitu Pulau Merbau, Pulau Tebing Tinggi, Pulau Rangsang dan Pulau Padang (Badan Pusat Statistik Kabupaten Kepulauan Meranti, 2010).

Sebagai kabupaten yang baru, dalam penyusunan arahan pengembangan komoditas wilayah perlu mempertimbangkan pemanfaatan sumberdaya lahan yang berpegang pada prinsip berkeadilan dan berkelanjutan (Hidayat, 2009). Pemanfaatan sumberdaya lahan berkeadilan dan berkelanjutan difungsikan agar dapat memberi kesejahteraan bagi siapa saja yang berkepentingan dengan sumberdaya lahan tersebut, baik itu masyarakat, pemerintah ataupun swasta.

Penyusunan arahan pengembangan komoditas perlu mempertimbangkan pemanfaatan lahan yang optimal. Kesalahan dalam pengelolaan lahan yang melebihi daya dukung lahan akan menyebabkan terjadinya kerusakan lahan (Nugroho, 2000). Arahan pengembangan komoditas pada suatu lahan mencakup perencanaan penggunaan lahan untuk pengembangan komoditas tertentu. Komoditas yang terpilih adalah komoditas yang mempunyai nilai ekonomis yang tinggi, hasil evaluasi kesesuaian lahannya sesuai serta dibudidayakan masyarakat dan memiliki dukungan infrastruktur dan kelembagaan yang cukup. Ketidaktahuan untuk mengendalikan suatu penggunaan lahan untuk pengembangan komoditas dapat diatasi dengan menyusun perencanaan penggunaan lahan. Perencanaan penggunaan lahan akan menyediakan keperluan lahan untuk pembangunan, baik untuk sektor pertanian ataupun sektor non pertanian. Dengan tersusunnya suatu perencanaan penggunaan lahan untuk pengembangan komoditas, maka kerusakan lahan dapat dihindari atau diminimumkan dan dapat mengupayakan suatu sistem penggunaan lahan yang berkesinambungan.

Mengingat usia kabupaten ini yang relatif muda, arahan pengembangan komoditas belum tersedia secara lengkap. Sebagai kabupaten yang baru terbentuk banyak aspek yang harus diperhatikan agar pemanfaatan atau penggunaan lahan untuk pengembangan komoditas wilayah lebih efektif dan berdaya guna. Berhubung arahan pengembangan komoditas wilayah di Kabupaten Kepulauan Meranti belum disusun, maka perlu dilakukan penelitian analisis kesesuaian dan ketersediaan lahan serta arahan pengembangan komoditas pertanian di Kabupaten Kepulauan Meranti. Hasil dari penelitian ini diharapkan dapat digunakan sebagai masukan pada pemerintah daerah dalam menyusun arahan pengembangan komoditas wilayah ke depan.

Tujuan penelitian ini adalah: (1) menganalisis komoditas unggulan di Kabupaten Kepulauan Meranti, (2) menganalisis kesesuaian lahan untuk pengembangan berbagai komoditas pertanian, (3) mengkaji dan menganalisis ketersediaan lahan yang berpotensi pengembangan untuk berbagai komoditas pertanian, serta (4) menyusun arahan pengembangan komoditas pertanian.

\section{BAHAN DAN METODE}

\section{Lokasi dan Data Penelitian}

Penelitian dilakukan di Kabupaten Kepulauan Meranti Provinsi Riau dan analisis data dilakukan di Studio Bagian Perencanaan dan Pengembangan Wilayah, Departemen Ilmu Tanah dan Sumberdaya Lahan, Fakultas Pertanian, Institut Pertanian Bogor. Gambar 1 menunjukkan lokasi penelitian.

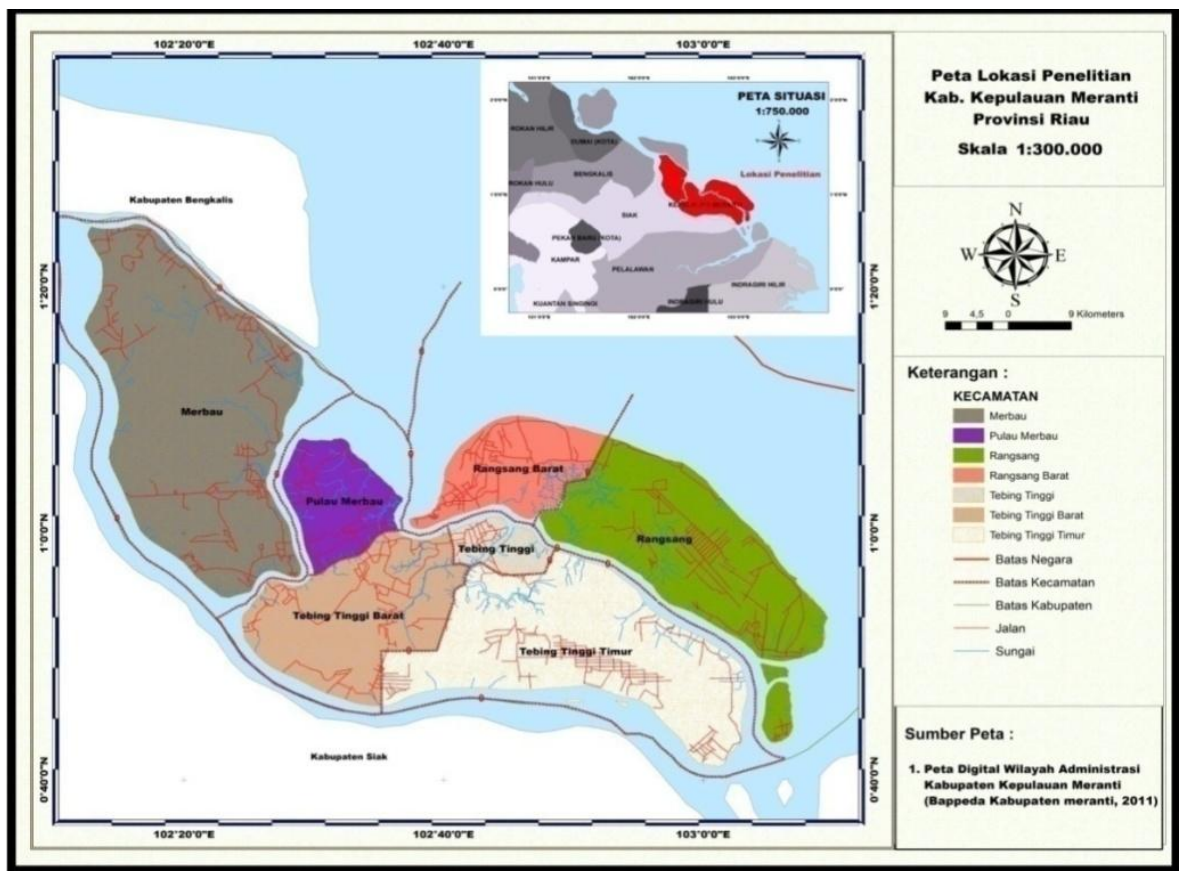

Gambar 1. Peta lokasi penelitian Kabupaten Kepulauan Meranti 
Data yang digunakan data sekunder, terdiri dari data luas panen komoditas pertanian tahun 2009 dan 2010 (BPS Kab. Kepulauan Meranti 2010 dan 2011), Peta Administrasi Kabupaten Kepulauan Meranti, Peta RTRW Kabupaten Kepulauan Meranti tahun 2011-2031 (Badan Perencanaan dan Pembangunan Daerah Kab. Kepulauan Meranti), peta satuan lahan Kabupaten Kepulauan Meranti (Pusat Penelitian Tanah dan Agroklimat, 1990), peta peruntukan kawasan menurut TGHK (tata guna hutan kesepakatan) dan perizinan (Dinas Kehutanan dan Perkebunan Kab. Kepulauan Meranti, 2011).

\section{Metode Penelitian}

Penelitian dilaksanakan dalam beberapa tahapan, yaitu: (1) Pengumpulan Data, meliputi pengumpulkan data berupa data spasial dan data statistik. (2) Analisis Data, unit terkecil wilayah yang digunakan dalam analisis adalah kecamatan, analisis dan pengolahan data yang digunakan adalah analisis spasial dilakukan dengan mendigitasi petapeta yang masih berbentuk data raster (peta analog) untuk diubah menjadi data vektor (peta digital). (3) Analisis Location Quotient (LQ) dan Shift Share Analysis (SSA) untuk mengetahui keunggulan komparatif dan keunggulan kompetitif wilayah. serta analisis kesesuaian lahan dan ketersediaan lahan. (4) Setelah tahap digitasi, tahapan selanjutnya adalah menumpangtindihkan peta-peta yang telah terdigitasi tersebut untuk mendapat peta digital kesesuaian lahan dan ketersediaan lahan yang digunakan untuk merencanakan pengembangan komoditas, (5) Interpretasi Hasil, berupa interpretasi hasil analisis data yang pada dasarnya merupakan proses perumusan hasil analisis dan pembahasan sebagai bahan penyusunan arahan pengembangan komoditas pertanian.

\section{Analisis Spasial}

Analisis spasial dilakukan dengan mendigitasi peta-peta yang masih berbentuk data raster (peta analog) untuk diubah menjadi data vektor (peta digital). Setelah tahap digitasi, tahapan selanjutnya adalah menumpang tepatkan peta-peta yang telah terdigitasi tersebut untuk mendapat peta digital kesesuaian lahan dan ketersediaan lahan yang digunakan untuk merencanakan pengembangan komoditas. Sebelum memproses analisis spasial terlebih dahulu dilakukan pemilihan komoditas dengan analisis LQ dan Shift-share. Uraian kedua teknik analisis tersebut adalah sebagai berikut:

\section{Location Quotient (LQ)}

Location Quotient (LQ) merupakan analisis untuk melihat keunggulan komparatif berbagai komoditas pertanian di Kabupaten Kepulauan Meranti dalam tingkat kecamatan. LQ bertujuan membandingkan aktifitas komoditas di kecamatan dalam aktifitas tertentu dengan total aktifitas komoditas tertentu di Kabupaten Kepulauan Meranti. LQ didefinisikan sebagai rasio persentase dari total aktifitas komoditas pada kecamatan ke-i terhadap persentase aktifitas total komoditas di Kabupaten Kepulauan Meranti. Analisis LQ digunakan untuk menunjukkan ada tidaknya pemusatan aktifitas komoditas pertanian pada kecamatan di Kabupaten Kepulauan Meranti. Data yang digunakan dalam analisis LQ adalah data luas lahan komoditas pertanian di Kabupaten Kepulauan Meranti tahun 2010 terdiri dari 21 Komoditas pertanian yang dikelompokkan menjadi 4 kelompok yaitu tanaman perkebunan, pangan, buah-buahan dan sayursayuran. Asumsi dalam analisis ini adalah (1) kondisi geografis relatif seragam, (2) pola-pola aktifitas bersifat seragam, dan (3) setiap aktifitas menghasilkan produk yang sama. Menurut Blakely (1994) persamaan indeks LQ adalah :

$$
L Q_{I J}=\frac{X_{I J} / X_{L}}{X_{. J} / X_{.}}
$$

$$
\begin{aligned}
& \text { dimana: } \mathrm{X}_{\mathrm{ij}} \quad \text { : derajat aktifitas komoditas (luas lahan) } \\
& \text { ke-j di Kecamatan ke- } i \\
& \mathrm{X}_{i .} \quad \text { : total aktifitas komoditas (luas lahan) di } \\
& \text { Kecamatan ke- } i \\
& \mathrm{X}_{\cdot \mathrm{j}} \quad \text { : total aktifitas komoditas (luas lahan) } \\
& \text { ke-j di semua Kecamatan } \\
& \text { X.. } \quad \text { : derajat aktifitas total komoditas (luas } \\
& \text { lahan) di Kabupaten Kepulauan } \\
& \text { Meranti }
\end{aligned}
$$

Nilai $\mathrm{LQ}_{\mathrm{ij}}>1$, menunjukkan terjadinya konsentrasi atau pemusatan suatu aktifitas komoditas ke-j di Kecamatan ke-i secara relatif dibandingkan dengan total wilayah. Jika nilai $\mathrm{LQ}_{\mathrm{ij}}=1$, maka aktifitas komoditas ke-j di Kecamatan ke-i tersebut mempunyai pangsa aktifitas setara dengan pangsa total aktifitas komoditas dalam Kabupaten Kepulauan Meranti. Jika nilai $\mathrm{LQ}_{\mathrm{ij}}<1$, maka aktifitas komoditas ke-j di Kecamatan ke-i tersebut mempunyai pangsa relatif lebih kecil dibandingkan dengan aktifitas yang secara umum di temukan di seluruh kecamatan di Kabupaten Kepulauan Meranti.

\section{Shift Share Analysis (SSA)}

Shift share analysis (SSA) merupakan analisis untuk melihat keunggulan kompetitif komoditas pertanian di Kabupaten Kepulauan Meranti. SSA merupakan salah satu dari sekian banyak teknik analisis untuk memahami pergeseran struktur aktifitas komoditas pertanian di Kabupaten Kepulauan Meranti dibandingkan dengan dua titik waktu, aktifitas komoditas tahun 2009 dan 2010. Data yang digunakan dalam analisis ini adalah data luas lahan komoditas pertanian tahun 2009 dan 2010. Terdapat tiga komponen yang dapat dianalisis yaitu komponen regional share, komponen proportional shift, dan komponen differential shift. Komponen regional share menunjukkan pertumbuhan komoditas pertanian di Kabupaten Kepulauan Meranti pada dua titik waktu, yaitu tahun 2009 dan 2010. Komponen proportional shift menentukan pertumbuhan total aktifitas komoditas tertentu secara relatif, dibandingkan dengan pertumbuhan secara umum di Kabupaten Kepulauan Meranti. Komponen differential shift menjelaskan tingkat kompetitif aktifitas komoditas tertentu dibandingkan dengan pertumbuhan total aktifitas komoditas tertentu tersebut di Kabupaten Kepulauan Meranti.

Persamaan SSA (Shift share analysis) adalah sebagai berikut : 


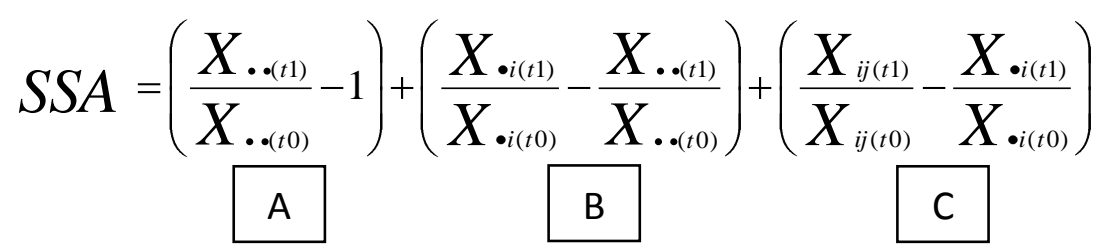

\section{B}

\section{c}

\section{A}

Dimana:
A $\quad=$ Komponen share
B $\quad=$ Komponen proportional shift
$\mathrm{C} \quad=$ Komponen differential shift
X.. = Nilai total aktifitas komoditas di Kabupaten Kepulauan
Meranti
$\mathrm{Xij}=$ Nilai aktifitas komoditas tertentu dalam Kecamatan
$\mathrm{X} . \mathrm{i}=$ Nilai total aktifitas komoditas tertentu di Kabupaten
Kepualaun Meranti
$\mathrm{t}_{1} \quad=$ Nilai tahun akhir
$\mathrm{t}_{2} \quad=$ Nilai tahun awal

\section{Analisis Kesesuaian Lahan}

Analisis kesesuaian lahan untuk pengembangan komoditas pertanian di Kabupaten Kepulauan Meranti dilakukan dengan unit evaluasi satuan lahan (land unit). Penetapan kesesuaian lahan di Kabupaten Kepulauan meranti berdasarkan metode FAO (1976) yaitu membandingkan persyaratan tumbuh tanaman (komoditas pertanian) dengan kualitas lahan.

Menurut Sitorus (2004) terdapat beberapa sistem klasifikasi kesesuaian lahan. Sistem klasifikasi kesesuaian lahan yang dipakai di Indonesia adalah sistem yang dikembangkan oleh FAO (1976). Tiga tingkatan kesesuaian lahan yang digunakan dalam penelitian ini, yaitu: pertama ordo menunjukkan suatu lahan sesuai (S) atau tidak sesuai $(\mathrm{N})$ untuk pengembangan komoditas pertanian tertentu. Kedua kelas menunjukkan tingkat kesesuaian lahan dari masing-masing ordo, SI (sangat sesuai), S2 (cukup sesuai), S3 (sesuai marginal) dan untuk ordo yang tidak sesuai dalam analisis ini hanya dilakukan pada tingkat ordo $(\mathrm{N})$. Ketiga sub-kelas menunjukkan faktor pembatas atau macam perbaikan yang diperlukan dalam kelas tersebut.

Penilaian terhadap kesesuaian lahan di Kabupaten Kepulauan Meranti ditujukan untuk pengembangan komoditas unggulan pertanian. Penilaian kesesuaian lahan meliputi tanaman perkebunan (karet, kelapa, sagu dan kopi), tanaman pangan (padi sawah, jagung, ketela rambat dan ketela pohon), buah-buahan (sawo, pepaya, pisang, jambu biji, sukun, nenas, dan manggis) dan sayur-sayuran (terung, kacang panjang, cabe (cabe besar dan cabe rawit) dan ketimun. Penelitian ini mencakup 20 komoditas, tetapi untuk komoditas pinang dalam penilaian kesesuaian lahan tidak dilakukan evaluasi karena ketidaktersediaan data dan sagu hanya dilakukan evaluasi dengan data yang terbatas. Karakteristik lahan yang dievaluasi adalah karakteristik fisik lahan yang sulit atau tidak bisa dirubah, tetapi mempengaruhi pertumbuhan tanaman (komoditas). Karakteristik lahan tersebut meliputi : temperatur (tc) (temperatur rerata, ketinggian), ketersediaan air (wa), ketersediaan oksigen (oa) (drainase), media perakaran (rc), (tekstur, kedalaman tanah), gambut (ketebalan dan kematangan), retensi hara (nr) (KTK liat, pH, C-Organik), toksisitas (xc) (salinitas), bahaya sulfidik (xs) (kedalaman sulfidik), bahaya erosi (eh) (lereng) dan penyiapan lahan (lp) (singkapan batuan).

\section{Analisis Ketersediaan Lahan}

Analisis ketersediaan lahan bertujuan untuk mengetahui status lahan yang sesuai apakah masih tersedia untuk suatu pengembangan komoditas unggulan. Lahan tersedia ini merupakan bagian penting dalam arahan pengembangan komoditas karena menyangkut ketersediaan akan suatu sumberdaya alam. Analisis ketersediaan lahan menggunakan data: peta fungsi dan peruntukan kawasan menurut TGHK (tata guna hutan kesepakatan), perizinan skala besar dan peta RTRW (pola ruang dan pengembangan kawasan perkotaan). Kedua, peta tersebut ditumpangtindihkan untuk melihat ketersediaan lahan. Hasil tumpang tindih peta-peta tersebut menghasilkan lahan tersedia dan tidak tersedia.

Lahan yang dikategorikan tidak tersedia untuk pengembangan komoditas pertanian pada peta fungsi dan peruntukan kawasan menurut TGHK dan perizinan adalah lahan yang berada dalam hutan lindung, suaka margasatwa, hutan produksi terbatas dan hutan produksi tetap serta yang telah diperuntukkan perizinannya untuk pihak swasta (perusahaan). Lahan yang berada di hutan produksi konversi (HPK) dan areal penggunaan lain (APL) dikategorikan sebagai lahan tersedia. Lahan yang dikategorikan tidak tersedia pada peta RTRW adalah lahan yang berada dalam kawasan lindung seperti kawasan hutan lindung, sempadan pantai, hutan mangrove/bakau dan suaka margasatwa. Lahan tersedia, lahan yang berada dalam kawasan budidaya seperti kawasan hutan produksi (hutan produksi konversi) dan kawasan pertanian. Lahan yang berada dalam kawasan yang telah terdaftar untuk kegiatan tertentu (kawasan pengembangan perkotaan, pemukiman, industri dan pertambangan) dikategorikan tidak tersedia.

\section{Arahan Pengembangan Komoditas}

Arahan pengembangan komoditas setiap kecamatan di kabupaten Kepulauan Meranti disusun berdasarkan komoditas yang memiliki keunggulan komparatif dan kompetitif serta dengan mempertimbang- 
kan hasil analisis kesesuaian dan ketersediaan lahan. Komoditas yang memiliki keunggulan komparatif dan kompetitif menjadi prioritas utama dalam arahan pengembangannya. Komoditas yang mempunyai keunggulan komparatif namun tidak kompetitif atau sebaliknya tidak dijadikan prioritas utama dalam arahan pengembangan komoditas. Penetapan pengalokasian pengembangan komoditas pertanian setiap kecamatan di Kabupaten Kepulauan Meranti yaitu komoditas yang memiliki LQ>1 dan DF>0 (SSA). Komoditas yang tidak termasuk kedalam komoditas unggulan, namun memiliki LQ $>1$ dan $\mathrm{DF}<0$ (SSA) atau sebaliknya dapat dialokasikan untuk pengembangan tetapi tidak dijadikan prioritas utama dalam pengalokasian pengembangan komoditas. Pemilihan lokasi berdasarkan lahan sesuai dan tersedia. Lahan sesuai dimulai dari kelas S1 (sangat sesuai), diikuti dengan lahan kelas S2 (cukup sesuai) dan S3 (sesuai marginal). Selanjutnya pemilihan lokasi berdasarkan lahan-lahan yang memiliki ketersediaan untuk arahan pengembangan komoditas. Lahan dengan status tersedia dapat dialokasikan untuk pengembangan komoditas, sedangkan yang tidak tersedia tidak dialokasikan untuk pengembangan komoditas.

\section{HASIL DAN PEMBAHASAN}

\section{Pemilihan Komoditas untuk Pengembangan Komoditas Pertanian}

Pada penelitian ini komoditas yang dikaji adalah komoditas pertanian yang meliputi tanaman perkebunan (karet, kelapa, sagu, kopi, dan pinang), tanaman pangan (padi sawah, jagung, ketela rambat, dan ketela pohon), buah-buahan (sawo, pepaya, pisang, jambu biji, sukun, nenas dan manggis) dan sayur-sayuran (terung, kacang panjang, cabe besar, cabe rawit dan ketimun). Data yang digunakan adalah berupa data luas panen komoditas pertanian tahun 2009 dan 2010. Hasil perhitungan Location Quotient (LQ) terhadap luas panen komoditas pertanian tahun 2010 di Kabupaten Kepulauan Meranti, menunjukkan beberapa komoditas mempunyai nilai indek LQ > 1 dan lebih besar dari yang lainnya. Komoditas karet memiliki nilai LQ (3.57) paling besar diantara komoditas tanaman perkebunan lainnya, di Kecamatan Pulau Merbau. Komoditas tanaman pangan padi sawah memiliki nilai LQ (4.88) lebih besar dari lainnya, di Kecamatan Rangsang. Komoditas buah-buahan pisang memiliki nilai LQ (8.00) lebih besar dari yang lainnya, di Kecamatan Tebing
Tinggi. Komoditas sayur-sayuran cabe besar memiliki nilai LQ (6.38) lebih besar dari yang lainnya, di Kecamatan Tebing Tinggi. Berdasarkan analisis Location Quotient (LQ) di peroleh komoditas yang memiliki keunggulan komparatif di Kabupaten Kepulauan Meranti. Komoditas yang memiliki keunggulan komparatif tersebut adalah komoditas dengan nilai LQ $>1$.

Untuk melengkapi hasil analisis LQ dilakukan perhitungan Shift share analysis (SSA). Data yang digunakan adalah data luas panen berbagai komoditas di setiap kecamatan di Kabupaten Kepulauan Meranti tahun 2009 dan 2010. Hal ini dikarenakan Kabupaten ini masih baru terbentuknya pada tahun 2008 sehingga data yang tersedia hanyalah data luas panen berbagai komoditas tahun 2009 dan 2010. Untuk perhitungan SSA, beberapa kecamatan harus digabung yakni Kecamatan Merbau dengan Pulau Merbau dan Kecamatan Tebing Tinggi dan Tebing Tinggi Timur. Hal tersebut dilakukan karena pada tahun 2010 kecamatan tersebut mengalami pemekaran. Hasil perhitungan SSA untuk dua titik tahun menunjukkan bahwa komponen laju pertumbuhan total pengembangan komoditas di Kabupaten Kepulauan Meranti sebesar 5.9\% (regional share). Untuk laju pertumbuhan komoditas (proportional shift), komoditas tanaman perkebunan, tanaman pangan (kecuali jagung), dan sayuran-sayuran (kecuali terung) mempunya nilai berkisar dari 0,0 sampai negatif (-) artinya komoditas-komoditas tersebut laju pertumbuhannya lebih rendah dibandingakan laju pertumbuhan komoditas secara keseluruhan. Komoditas buah-buahan menunjukkan nilai positif $(>0)$ artinya komoditas buah-buahan laju pertumbuhannya lebih tinggi dibandingkan laju pertumbuhan total komoditas diwilayah tersebut

Komoditas dengan nilai Differential shift lebih besar dari $0 \quad(\mathrm{DF}>0)$ menunjukkan komoditas tersebut memiliki keunggulan kompetitif, sedangkan nilai DF $<0$ menunjukkan komoditas tersebut tidak kompetitif. Untuk komoditas terung pada analisis DF tidak didapatkan hasil perhitungan, karena komoditas ini berdasarkan data tahun 2009 belum ada yang diusahakan pada setiap kecamatan, sehingga merupakan komoditas yang baru di usahakan pada tahun 2010. Berdasarkan analisis LQ dan SSA untuk melihat keunggulan komparatif dan kompetitif diperoleh beberapa komoditas yang memiliki potensi untuk dikembangkan. Potensi pengembangan komoditas pertanian setiap kecamatan di Kabupaten Kepulauan Meranti dapat dilihat pada Tabel 1.

Tabel 1. Potensi pengembangan komoditas setiap kecamatan di Kabupaten Kepulauan Meranti

\begin{tabular}{llll}
\hline Kecamatan & \multicolumn{1}{c}{ Komparatif } & \multicolumn{1}{c}{ Kompetitif } & \multicolumn{1}{c}{ Komoditas Unggulan } \\
\hline Tebing Tinggi & Pisang & Kelapa & Jagung, Ketela rambat (tanaman pangan) \\
& Cabe besar & Padi sawah & Cabe besar, Cabe rawit, Kacang panjang, Ketimun \\
& Cabe rawit & Jagung & (sayur-sayuran) \\
& Kacang panjang & Ketela rambat & \\
& Ketimun & Kacang panjang & \\
& Ketela rambat & Cabe besar & \\
& Jagung & Cabe rawit & Ketimun \\
& & & \\
\end{tabular}


Tabel 1. (Lanjutan)

\begin{tabular}{|c|c|c|c|}
\hline Tebing Tinggi Timur & Sagu & & \\
\hline Tebing Tinggi Barat & $\begin{array}{l}\text { Karet } \\
\text { Sagu } \\
\text { Ketela rambat } \\
\text { Jagung } \\
\text { Pepaya } \\
\text { Sukun } \\
\text { Nenas } \\
\text { Terung } \\
\text { Ketimun } \\
\text { Kacang panjang } \\
\text { Cabe besar } \\
\text { Cabe rawit }\end{array}$ & $\begin{array}{l}\text { Kelapa } \\
\text { Sagu } \\
\text { Pinang } \\
\text { Padi sawah } \\
\text { Ketela rambat } \\
\text { Sawo } \\
\text { Pepaya } \\
\text { Pisang } \\
\text { Jambu biji } \\
\text { Sukun } \\
\text { Nenas } \\
\text { Manggis }\end{array}$ & $\begin{array}{l}\text { Sagu (tanaman perkebunan) } \\
\text { Ketela rambat (tanaman pangan) } \\
\text { Sukun, Pepaya, Nenas (buah-buahan) }\end{array}$ \\
\hline Rangsang & $\begin{array}{l}\text { Kelapa } \\
\text { Sawo } \\
\text { Nenas } \\
\text { Sukun }\end{array}$ & $\begin{array}{l}\text { Sagu, Kopi, } \\
\text { Pinang, Padi sawah, } \\
\text { Jagung, } \\
\text { Sawo, Pepaya, } \\
\text { Jambu biji, Pisang, } \\
\text { Nenas, } \\
\text { Ketimun }\end{array}$ & Sawo, Nenas (buah-buahan) \\
\hline Rangsang Barat & $\begin{array}{l}\text { Kopi } \\
\text { Pinang } \\
\text { Kelapa } \\
\text { Karet } \\
\text { Padi sawah } \\
\text { Manggis } \\
\text { Pisang } \\
\text { Pepaya }\end{array}$ & $\begin{array}{l}\text { Sagu, Kopi, Pinang, } \\
\text { Jagung } \\
\text { Ketela rambat, } \\
\text { Ketela pohon, } \\
\text { Sawo, Pepaya, } \\
\text { Pisang, Jambu biji, } \\
\text { Sukun, Nenas, } \\
\text { Manggis }\end{array}$ & $\begin{array}{l}\text { Kopi, Pinang (tanaman perkebunan) } \\
\text { Pisang, Pepaya, Manggis (buah-buahan) }\end{array}$ \\
\hline Merbau & $\begin{array}{l}\text { Karet } \\
\text { Sagu } \\
\text { Ketela pohon } \\
\text { Jagung } \\
\text { Jambu biji } \\
\text { Sukun } \\
\text { Terung } \\
\text { Cabe besar } \\
\text { Cabe rawit } \\
\text { Ketimun } \\
\text { Kacang panjang }\end{array}$ & $\begin{array}{l}\text { Sagu, Padi sawah, } \\
\text { Ketela pohon, } \\
\text { Pepaya, Pisang } \\
\text { Jambu biji, Nenas, } \\
\text { Manggis } \\
\text { Cabe besar, Cabe } \\
\text { rawit, } \\
\text { Ketimun }\end{array}$ & $\begin{array}{l}\text { Sagu (tanaman Perkebunan) } \\
\text { Ketela pohon (tanaman pangan) } \\
\text { Jambu biji (buah-buahan) } \\
\text { Cabe besar, Cabe rawit, Ketimun (sayur-sayuran) }\end{array}$ \\
\hline Pulau Merbau & Karet dan Pinang & & \\
\hline
\end{tabular}

\section{Kesesuaian Lahan untuk Komoditas Pertanian}

Untuk melengkapi informasi mengenai potensi wilayah di setiap kecamatan, dilakukan analisis kesesuaian lahan terhadap komoditas unggulan di Kabupaten Kepulauan Meranti. Evaluasi kesesuaian lahan dilakukan pada tingkat tinjau karena analisis dilakukan hanya berdasarkan pendekatan peta satuan lahan Kabupaten Kepulauan Meranti skala 1:250,000 (Puslitanak, 1990) yang disesuaikan dengan tabel kesesuaian lahan. Secara spasial penyebaran satuan satuan lahan di Kabupaten Kepulauan Meranti dapat dilihat pada Gambar 2 dan keterangan peta satuan lahan dapat dilihat pada Tabel 2.

Berdasarkan evaluasi kesesuaian lahan untuk komoditas unggulan sagu, pinang, kopi, jagung, ketela rambat, ketela pohon, sawo, pepaya, pisang, nenas, jambu biji, sukun, manggis, cebe besar, cabe rawit, kacang panjang dan ketimun (komoditas pinang tidak dilakukan evaluasi karena ketidaktersediaan data dan sagu hanya dilakukan evaluasi dengan data yang terbatas) satuan lahan yang sesuai dan tidak sesuai menunjukkan hasil kelas kesesuaian yang sama untuk setiap satuan lahan. Satuan lahan D.2.1.2 (Tropohemist), D.2.2.2 (Troposaprist,
Tropohemists), D.2.2.3 (Troposaprists, Tropohemists) dan D.2.3.2 (Troposaprists) adalah sesuai untuk setiap komoditas unggulan. Definisi lahan sesuai yang dimaksud adalah setiap satuan lahan yang dievaluasi kesesuaian lahannya, lahan sesuai dengan tingkat kesesuaian S3 (sesuai marginal) menunjukkan hasil yang sama untuk setiap satuan lahan yang sesuai. Satuan lahan Bf.4.3 (Sulfaquents, Hydraquents), Bf.4.4 (Sulfaquents, Hydraquents), Bq.2 (Tropopsamments) dan D.2.1.3 (Troposaprists, Tropohemists dan Tropofibrists) tidak sesuai untuk semua komoditas unggulan. Satuan lahan Bf.4.3 dan Bf.4.4 (untuk jenis Sulfaquent) berdasarkan kelas kesesuaian lahan untuk berbagai komoditas unggulan memiliki tingkat kesesesuaian $\mathrm{N}$ (tidak sesuai) dengan faktor pembatas salinitas (xc) dan kedalaman sulfidik (xs) yang dapat menimbulkan masalah keasaman pada tanah tersebut. Satuan lahan Bf.4.3 dan Bf.4.4 termasuk fisiografi lahan rawa pasang surut, intrusi air laut yang besar sebaiknya lahan ini dilestarikan sebagai kawasan konservasi untuk menjaga tingginya intrusi air laut dan mencegah terjadinya abrasi. Satuan lahan Bq.2 termasuk kedalam tingkat kesesuaian lahan $\mathrm{N}$ dengan faktor pembatas rc (tekstur dan kedalaman tanah). Satuan lahan 
D.2.1.3 (Troposaprists, Tropohemists dan Tropofibrists) memiliki tingkat kesesuaian $\mathrm{N}$ dengan faktor pembatas rc (ketebalan gambut $>2$ meter). Untuk komoditas sagu dilakukan evaluasi dengan data yang terbatas. Hasil evaluasi kesesuaian lahan untuk sagu hampir sama dengan hasil analisis komoditas unggulan lainnya. Satuan Lahan D.2.1.3 dikategorikan tidak sesuai untuk pengembangan sagu karena ketebalan gambut lebih besar dari 2 meter dan miskin akan unsur hara.

Kesesuaian lahan untuk berbagai komoditas unggulan pertanian di Kabupaten Kepulauan Meranti memiliki tingkat kesesuaian S3 (sesuai marginal) untuk setiap satuan lahan yang sesuai dengan faktor pembatas sebagian besar adalah ketebalan gambut (rc) dan $\mathrm{pH}$ tanah (nr).
Penyebaran satuan lahan yang sesuai untuk setiap komoditas adalah sama. Untuk itu, secara spasial penyebaran lahan yang sesuai (sesuai marginal) dari delapan satuan lahan untuk berbagai komoditas unggulan pertanian di Kabupaten Kepulauan Meranti dapat dilihat pada Gambar 3. Luas satuan lahan yang sesuai untuk komoditas unggulan yang dipilih tertera pada Tabel 3.

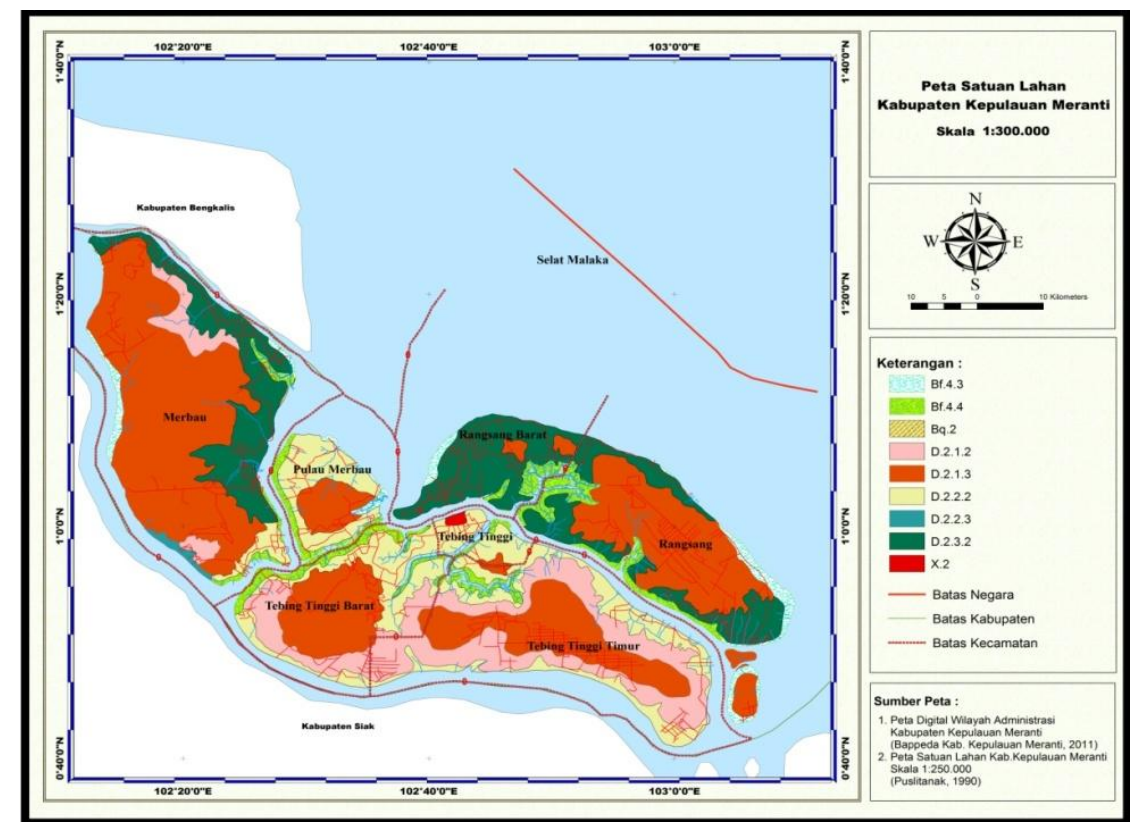

Gambar 2. Peta satuan lahan Kabupaten Kepulauan Meranti

Tabel 2. Keterangan peta satuan lahan

\begin{tabular}{|c|c|c|}
\hline $\begin{array}{l}\text { Satuan Lahan } \\
\text { (land unit) }\end{array}$ & Deskripsi Umum & Jenis Tanah \\
\hline Bf.4.3 & $\begin{array}{l}\text { Dataran pasang surut sepanjang pantai dan } \\
\text { bervegetasi bakau }\end{array}$ & $\begin{array}{l}\text { Sulfaquents } \\
\text { Hydraquents }\end{array}$ \\
\hline Bf.4.4 & $\begin{array}{l}\text { Dataran pasang surut sepanjang estuarin bervegetasi } \\
\text { mangrove campuran atau nipah }\end{array}$ & $\begin{array}{l}\text { Sulfaquents } \\
\text { Hydraquents }\end{array}$ \\
\hline Bq. 2 & Gumuk pasir dan sedimen kasar & Tropopsamments \\
\hline D.2.1.2 & Kubah gambut oligotrofik air tawar & $\begin{array}{l}\text { Troposaprists } \\
\text { Tropohemists } \\
\text { Tropofibrists }\end{array}$ \\
\hline D.2.1.3 & Kubah gambut oligotrofik air tawar & $\begin{array}{l}\text { Troposaprists } \\
\text { Tropohemists } \\
\text { Tropofibrists }\end{array}$ \\
\hline D.2.2.2 & Kubah gambut oligotrofik terpengaruh air asin & $\begin{array}{l}\text { Troposaprists } \\
\text { Tropohemists } \\
\text { Tropofibrists } \\
\text { Sulfihemists }\end{array}$ \\
\hline D.2.2.3 & Kubah gambut oligotrofik terpengaruh air asin & $\begin{array}{l}\text { Troposaprists } \\
\text { Tropohemists } \\
\text { Tropofibrists }\end{array}$ \\
\hline D.2.3.2 & $\begin{array}{l}\text { Kubah gambut yang telah diolah mengalami } \\
\text { pemadatan }\end{array}$ & $\begin{array}{l}\text { Sulfihemists } \\
\text { Troposaprists } \\
\text { Sulfihemists } \\
\text { Tropohemists }\end{array}$ \\
\hline $\mathrm{X} .2$ & $\begin{array}{l}\text { Daerah pemukiman, kota besar dan daerah } \\
\text { pembangunan }\end{array}$ & Sulfaquents \\
\hline
\end{tabular}




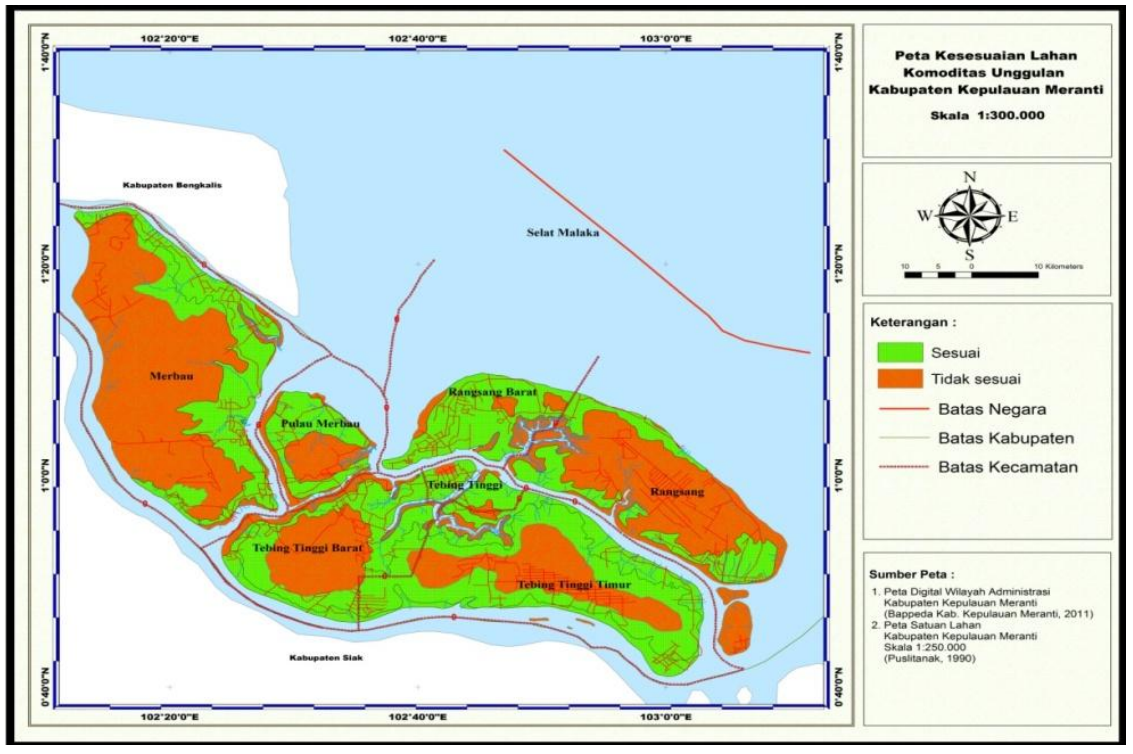

Gambar 3. Peta kesesuaian lahan komoditas unggulan di Kabupaten Kepulauan Meranti

Tabel 3. Luas satuan lahan yang sesuai untuk pengembangan komoditas unggulan

\begin{tabular}{|c|c|c|c|}
\hline Kecamatan & $\begin{array}{l}\text { Satuan lahan } \\
\text { yang sesuai }\end{array}$ & $\begin{array}{l}\text { Luas satuan lahan } \\
\text { yang sesuai (ha) }\end{array}$ & Komoditas Unggulan \\
\hline Merbau & $\begin{array}{l}\text { D.2.1.2, D.2.2.2, } \\
\text { D.2.2.3 dan D.2.3.2 }\end{array}$ & 35,289 & $\begin{array}{l}\text { Sagu, ketela pohon, Jambu biji, cabe } \\
\text { (cabe besar dan cabe rawit), dan ketimun }\end{array}$ \\
\hline Pulau Merbau & D.2.2.2 & 11,646 & Karet* dan Pinang* \\
\hline Rangsang & D.2.3.2 & 18,956 & Sawo dan nenas \\
\hline Rangsang Barat & D.2.3.2 & 19,584 & Kopi, Pinang, pisang pepaya dan manggis \\
\hline Tebing Tinggi & D.2.2.2 & 73.50 & $\begin{array}{l}\text { Jagung, ketela rambat, cabe (cabe besar } \\
\text { dan cabe rawit), kacang panjang dan } \\
\text { ketimun }\end{array}$ \\
\hline Tebing Tinggi Barat & $\begin{array}{l}\text { D.2.1.2 dan } \\
\text { D.2.2.2 }\end{array}$ & 25,266 & $\begin{array}{l}\text { Sagu, ketela rambat, sukun, pepaya dan } \\
\text { nenas }\end{array}$ \\
\hline Tebing Tinggi Timur & $\begin{array}{l}\text { D.2.1.2 dan } \\
\text { D.2.2.2 }\end{array}$ & 48,388 & Sagu* \\
\hline
\end{tabular}

*hanya berdasarkan keunggulan komparatif

\section{Ketersediaan Lahan untuk Pengembangan Komoditas}

Hasil analisis ketersediaan lahan untuk pengembangan komoditas ini diperoleh lahan yang termasuk kategori lahan tersedia yaitu lahan yang dapat direncanakan untuk pengembangan komoditas pertanian secara umum, sedangkan yang tidak tersedia merupakan lahan yang tidak dapat direncanakan untuk pengembangan komoditas pertanian. Keterbatasan data dalam penelitian ini, analisis ketersediaan lahan tidak bisa mencakup komoditas pertanian secara spesifik, sehingga hanya diperoleh hasil analisis ketersediaan lahan untuk pertanian secara umum.
Hasil analisis kesesuaian dan ketersediaan Lahan diperoleh lahan sesuai dan tersedia. Lahan ini dapat memberikan gambaran mengenai lahan-lahan yang memiliki potensi untuk pengembangan komoditas wilayah. Suatu perencanaan pengembangan komoditas wilayah (pertanian) membutuhkan informasi mengenai kesesuaian atau kemampuan dan ketersediaan lahan, agar lahan-lahan tersebut dapat produktif secara berkesinambungan serta meminimalisir terjadinya konflik lahan akibat adanya tumpang tindih lahan karena status lahan yang tidak jelas. Hasil analisis ketersediaan lahan terhadap lahan yang sesuai untuk pengembangan komoditas unggulan dapat dilihat pada Tabel 4. 
Tabel 4. Luas lahan sesuai dan tersedia untuk pengembangan komoditas unggulan di Kabupaten Kepulauan Meranti (ha)

\begin{tabular}{lrrrr}
\hline \multirow{2}{*}{ Kecamatan } & \multicolumn{2}{c}{ Luas Lahan Sesuai (ha) } & Total luas lahan (ha) & \% Luas tersedia (4) \\
\cline { 2 - 3 } & Tersedia (1) & Tidak tersedia (2) & & \\
\hline Merbau & 22,041 & 13,248 & 108,198 & 20.37 \\
Pulau Merbau & 6,213 & 5,433 & 20,638 & 30.10 \\
Rangsang & 12,562 & 6,394 & 64,126 & 19.59 \\
Rangsang Barat & 16,505 & 3,079 & 24,206 & 68.19 \\
Tebing Tinggi & 3,242 & 4,108 & 8,382 & 38.68 \\
Tebing Tinggi Barat & 17,725 & 75,41 & 41,724 & 42.48 \\
Tebing Tinggi Timur & 29,989 & 18,399 & 75,104 & 39.93 \\
\hline Jumlah & 108,277 & 50,661 & 342,378 & 31.62 \\
\hline
\end{tabular}

Tabel 4 merupakan luas lahan dari satuan lahan yang sesuai dan tersedia untuk pengembangan komoditas unggulan. Luas lahan sesuai dan tersedia sebesar 108,277 ha $(31.62 \%$ dari luas kabupaten), dan lahan sesuai tetapi tidak tersedia sebesar 50,661 ha $(14.80 \%$ dari luas kabupaten). Luas lahan keseluruhan sebesar 342,378 ha. Lahan yang sesuai dan tersedia paling luas terdapat di
Kecamatan Tebing Tinggi Timur (29,989 ha) dan Merbau (22,041 ha), sedangkan paling sedikit terdapat pada Kecamatan Tebing Tinggi (3,242 ha) dan Pulau Merbau (6,213 ha). Secara spasial kesesuaian dan ketersediaan lahan untuk pengembangan komoditas pertanian (komoditas unggulan) di Kabupaten Kepulauan Meranti dapat dilihat pada Gambar 4.

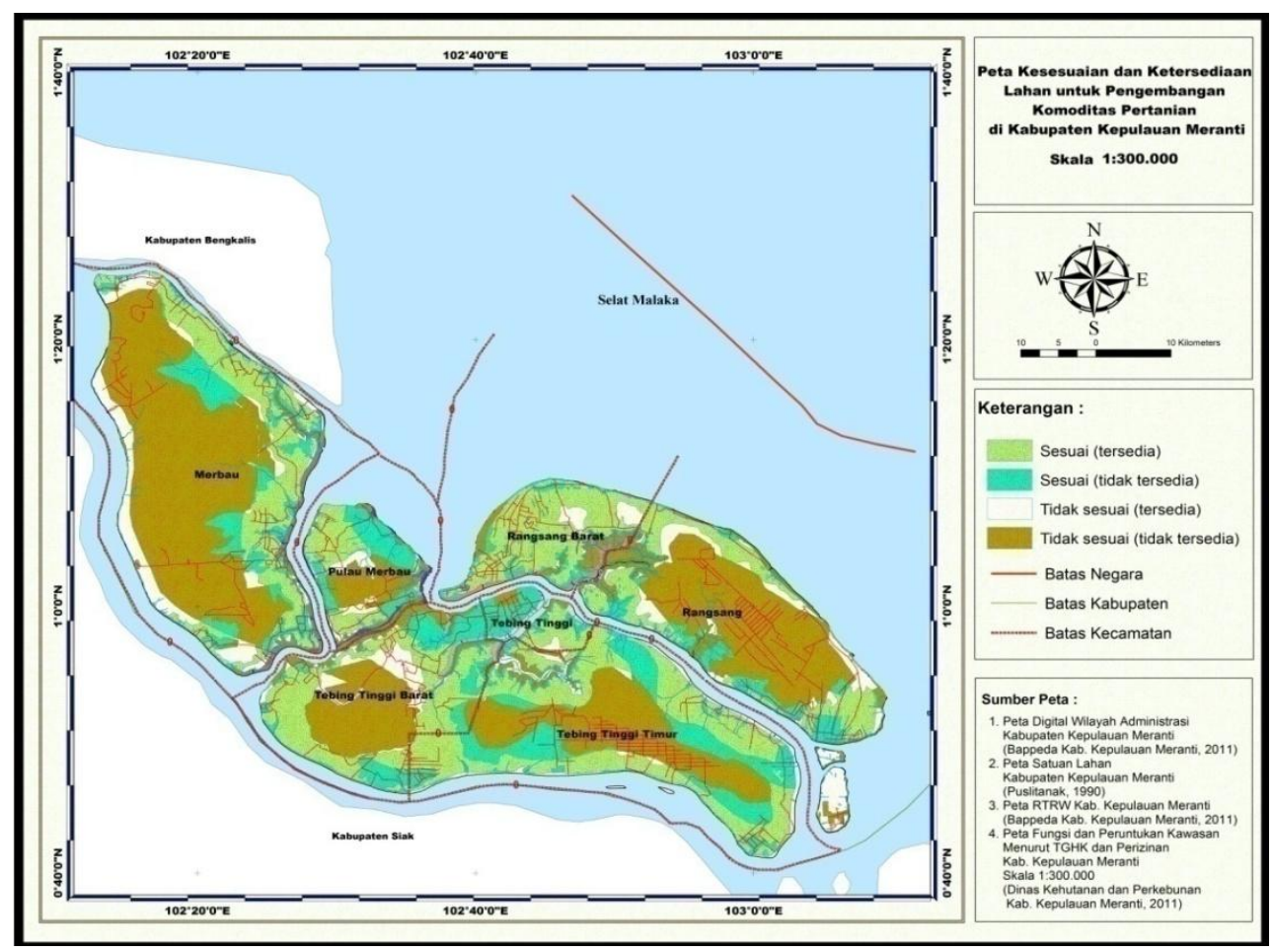

Gambar 4. Peta kesesuaian dan ketersediaan lahan untuk pengembangan komoditas pertanian (komoditas unggulan) di Kabupaten Kepulauan Meranti

\section{Arahan Pengembangan Komoditas di Kabupaten Kepulauan Meranti}

Penyusunan arahan pengembangan komoditas setiap kecamatan di Kabupaten Kepulauan Meranti dilakukan berdasarkan hasil analisis kesesuaian dan ketersediaan lahan terhadap komoditas unggulan. Luas total satuan lahan yang sesuai dan tersedia dari semua kecamatan untuk pengembangan komoditas unggulan adalah sebesar $\pm 108,227$ ha. Komoditas yang akan dikembangkan pada suatu daerah ditentukan dengan pertimbangan bahwa komoditas tersebut memiliki keunggulan komparatif dan kompetitif. Setelah ditentukan komoditas yang akan dikembangkan lalu dilihat kesesuaian lahannya. Setelah penentuan komoditas dan pertimbangan kesesuaian lahan tahapan selanjutnya adalah mempertimbangkan aspek ketersediaan lahan untuk mengetahui status lahan yang sesuai tersebut tersedia untuk pengembangan komoditas unggulan. Pengecualian dilakukan dalam penyusunan arahan pengembangan komoditas untuk Kecamatan Pulau Merbau dan Tebing Tinggi Timur, dimana arahan pengembangan komoditas hanya berdasarkan keunggulan komparatif. Dua kecamatan ini baru dimekarkan, sehingga tidak memungkinkan untuk penentuan komoditas yang memiliki keunggulan kompetitif (SSA).

Arahan pengembangan komoditas pertanian di Kabupaten Kepulauan Meranti hasil penelitian ini apabila akan diterapkan atau diaplikasikan masih memerlukan telaahan terhadap beberapa parameter yang tidak 
dilakukan dalam penelitian ini seperti preferensi masyarakat terhadap lahan yang dimiliki apakah bisa diperuntukkan atau dialihfungsikan untuk pengembangan komoditas unggulan tersebut. Berdasarkan pertimbangan hasil analisis kesesuaian dan ketersediaan lahan terhadap komoditas unggulan maka disusunlah arahan pengembangan komoditas setiap kecamatan di Kabupaten Kepulauan Meranti seperti tertera pada Tabel 5.

Tabel 5. Arahan pengembangan komoditas pertanian setiap kecamatan di Kabupaten Kepulauan Meranti

\begin{tabular}{lllll}
\hline Kecamatan & $\begin{array}{l}\text { Tanaman } \\
\text { Perkebunan }\end{array}$ & Tanaman Pangan & Buah-buahan & Sayur-sayuran \\
\hline Merbau & Sagu & Ketela pohon & Jambu biji & $\begin{array}{l}\text { Cabe besar } \\
\text { Cabe rawit } \\
\text { Ketimun }\end{array}$ \\
Pulau Merbau & Karet & & & \\
Rangsang & Pinang & & Sawo & \\
Rangsang Barat & Kopi & & Nenas & \\
& Pinang & & Pisang & \\
Tebing Tinggi & & Pepaya & \\
& & Magugis & Cabe besar \\
Tebing Tinggi Barat & Sagu & Ketela rambat & & Cabe rawit Kacang panjang \\
& & Ketela rambat & Pepaya & Ketimun \\
Tebing Tinggi Timur & Sagu & & Sukun & \\
\hline
\end{tabular}

\section{SIMPULAN}

1. Komoditas unggulan di Kabupaten Kepulauan Meranti berdasarkan hasil analisis LQ dan SSA adalah sagu, pinang dan kopi (tanaman perkebunan), jagung, ketela rambat dan ketela pohon (tanaman pangan), sawo, pepaya, pisang, nenas, jambu biji, sukun dan manggis (buah-buahan) dan cabe besar, cabe rawit, kacang panjang dan ketimun (sayur-sayuran).

2. Hasil analisis kesesuaian lahan untuk pengembangan berbagai komoditas unggulan di Kabupaten Kepulauan Meranti menunjukkan satuan lahan D.2.1.2 (Tropohemist), D.2.2.2 (Troposaprist, Tropohemists), D.2.2.3 (Troposaprists, Tropohemists) dan D.2.3.2 (Troposaprists) sesuai untuk setiap komoditas unggulan, dengan luas lahan yang sesuai 166.478 ha dengan tingkat kesesuaian S3 (sesuai marginal). Satuan lahan Bf.4.3 (Sulfaquents dan Hydraquents) Bf.4.4 (Sulfaquents dan Hydraquents), Bq.2 (Tropopsamments) dan D.2.1.3 (Troposaprists, Tropohemists dan Tropofibrists) tidak sesuai dengan luas 183,439 ha.

3. Hasil analisis ketersediaan lahan yang berpotensi untuk pengembangan berbagai komoditas unggulan di Kabupaten Kepulauan Meranti menunjukkan luas lahan yang sesuai dan tersedia untuk pengembangan komoditas 108,277 ha (31.62\%) dan lahan sesuai tetapi tidak tersedia 50,661 ha (14.80\%).

4. Arahan pengembangan komoditas unggulan pertanian setiap kecamatan di Kabupaten Kepulauan Meranti berturut-turut adalah sebagai berikut: Kecamatan Merbau adalah sagu (tanaman perkebunan), ketela pohon (tanaman pangan), jambu biji (buah-buahan) dan cabe besar, cabe rawit dan ketimun (sayur-sayuran). Kecamatan Pulau Merbau adalah karet dan pinang (tanaman perkebunan). Rangsang adalah sawo dan nenas (buah-buahan). Kecamatan Rangsang Barat adalah kopi dan pinang (tanaman perkebunan), pisang pepaya dan manggis (komoditas buah-buahan). Kecamatan Tebing Tinggi adalah ketela rambat dan jagung (tanaman pangan), dan cabe besar, cabe rawit, kacang panjang dan ketimun (sayur-sayuran). Kecamatan Tebing Tinggi Barat adalah sagu (tanaman perkebunan), ketela rambat (tanaman pangan), pepaya, sukun dan nenas (buah-buahan). Kecamatan Tebing Tinggi Timur komoditas yang dapat dikembangkan adalah sagu untuk tanaman perkebunan.

\section{DAFTAR PUSTAKA}

Badan Pusat Statistik Kabupaten Kepulauan Meranti. 2010. Kabupaten Kepulauan Meranti Dalam Angka. Selat Panjang.

Badan Pusat Statistik Kabupaten Kepulauan Meranti. 2011. Kabupaten Kepulauan Meranti Dalam Angka. Selat Panjang.

Balai Penelitian Tanah. 2003. Evaluasi Lahan untuk Komoditas Pertanian. Pusat Penelitian Tanah dan Agroklimat. Bogor.

Blakely, E.J. 1994. Planning Local Economic Development: Theory and Practice. $2^{\text {nd }}$ Edition. Sage Publications. International Education and Professional Publisher, Thousand Oaks, California.

Dinas Kehutanan dan Perkebunan Kabupaten Kepulauan Meranti. 2011. Peta Fungsi dan Peruntukan Kawasan menurut Tata Guna Hutan Kesepakatan (TGHK) dan Perizinan Kabupaten Kepulauan Meranti skala 1:300,000. 
Hidayat, A. 2009. Sumberdaya lahan Indonesia : potensi, permasalahan dan strategi pemanfaatan lahan. Jurnal Sumberdaya Lahan, 3:107-117.

Nugroho, P.S. 2000. Minimalisasi lahan kritis melalui pengelolaan sumberdaya lahan dan konservasi tanah dan air secara terpadu. Jurnal Teknologi dan Lingkungan, 10:73-82.

Pusat Penelitian dan Agroklimat. 1990. Peta Land Unit Kabupaten Kepulauan Meranti 1:250,000.
Puslitanak, Balitbang, Departemen Pertanian, Bogor.

Rustiadi, E., S. Saefulhakim, dan D.R. Panuju. 2011. Perencanaan dan Pengembangan Wilayah. Crestpent Press dan Yayasan Pustaka Obor Indonesia. Jakarta.

Sitorus, S.R.P. 2004. Evaluasi Sumberdaya Lahan. Penerbit Tarsito. Bandung. 